\title{
Biological Functions and Analytical Strategies of Sialic Acids in Tumor
}

\author{
Xiaoman Zhou ${ }^{1}$, Ganglong Yang ${ }^{1, *}$ and Feng Guan ${ }^{1,2, *(\mathbb{D})}$ \\ 1 The Key Laboratory of Carbohydrate Chemistry and Biotechnology, Ministry of Education, School of \\ Biotechnology, Jiangnan University, Wuxi 214122, China; zxm.jm@msn.cn \\ 2 Joint International Research Laboratory of Glycobiology and Medicinal Chemistry, College of Life Science, \\ Northwest University, Xi'an 710069, China \\ * Correspondence: glyanglife@jiangnan.edu.cn (G.Y.); guanfeng@nwu.edu.cn (F.G.); \\ Tel.: +86-0510-85197071 (G.Y.); +86-029-88302411 (F.G.)
}

Received: 18 November 2019; Accepted: 21 January 2020; Published: 22 January 2020

\begin{abstract}
Sialic acids, a subset of nine carbon acidic sugars, often exist as the terminal sugars of glycans on either glycoproteins or glycolipids on the cell surface. Sialic acids play important roles in many physiological and pathological processes via carbohydrate-protein interactions, including cell-cell communication, bacterial and viral infections. In particular, hypersialylation in tumors, as well as their roles in tumor growth and metastasis, have been widely described. Recent studies have indicated that the aberrant sialylation is a vital way for tumor cells to escape immune surveillance and keep malignance. In this article, we outline the present state of knowledge on the metabolic pathway of human sialic acids, the function of hypersialylation in tumors, as well as the recent labeling and analytical techniques for sialic acids. It is expected to offer a brief introduction of sialic acid metabolism and provide advanced analytical strategies in sialic acid studies.
\end{abstract}

Keywords: sialic acid; sialyltransferase; sialidase; tumor sialylation; sialic acid labeling

\section{Introduction}

The term "sialic acid" first appeared in 1952 to describe $N$-acetylneuraminic acid, a major product released by mild acid hydrolysis of glycolipids in the brain or salivary mucins [1,2]. Sialic acids are a subset of nine carbon acidic sugars that contain approximately fifty derivatives of neuraminic acids. The most common sialic acid derivatives found in mammals are $N$-acetylneuraminic acid (Neu5Ac) and $N$-glycolylneuraminic acid (Neu5Gc). Neu5Ac has an acetyl group on the fifth carbon atom (C5) while Neu5Gc has a glycolyl group instead. Interestingly, humans lack Neu5Gc caused by the mutation of the cytidine monophosphate $N$-acetylneuraminic acid hydroxylase $(C M A H)$ gene that codes the enzyme transforming CMP-Neu5Ac to CMP-Neu5Gc [3-5]. However, Neu5Gc is still found in the human glycome as it can be obtained through dietary sources [6]. In this review, "sialic acid" refers to Neu5Ac unless specifically emphasized.

In general, sialic acids normally exist as the terminal sugars in the periphery of oligosaccharides via different glycosidic linkages $(\alpha 2,3, \alpha 2,6 \alpha 2,8$, and $\alpha 2,9)$ [7]. Polysialic acid (PSA), a linear homopolymer of sialic acids mainly in $\alpha-2,8$ and/or $\alpha-2,9$ linkages, is usually attached to glycoproteins, such as the neural cell adhesion molecule (NCAM) [8,9]. Sialic acid metabolic pathways include the cooperation of certain enzymes that catalyze the biosynthesis, activation, and transfer of sialic acids to glycoconjugates, as well as the removal and degradation of sialic acids (Figure 1) [10]. In the human body, sialic acid biosynthesis starts at UDP-GlcNAc in the cytosol. Primitively, sialic acid synthesis is catalyzed by UDP-GlcNAc 2-epimerase/ManNAc-6-kinase (GNE), converting UDP-GlcNAc to ManNAc-6-P [11,12]. Next, ManNAc-6-P is transformed to Neu5Ac by Neu5Ac 9-phosphate synthase 
(NANS) with phosphoenolpyruvate (PEP) and Neu5Ac-9-phosphate phosphatase (NANP) [13,14]. Finally, Neu5Ac synthesized in cytosol is transferred to the nucleus and activated by the cytosine 5'-monophosphate $N$-acetylneuraminic acid synthetase (CMAS) to form CMP-Neu5Ac [15].

After activation, CMP-Neu5Ac is transferred to the glycoconjugates in the Golgi apparatus by a family of linkage-specific sialyltransferases. About 20 sialyltransferases have been cloned and characterized, including ST3GAL1-5, ST6GAL1, 2 and ST6GALNAC1-6, and ST8SIA1-6, which link Neu5Ac via its second carbon (C2) to the $\mathrm{C} 3, \mathrm{C} 6$ positions of other carbohydrates or the $\mathrm{C} 8, \mathrm{C} 9$ positions of another sialic acids, generating $\alpha 2,3-, \alpha 2,6-, \alpha 2,8$, or $\alpha 2,9-$ linked sialic acids, respectively [7]. Finally, sialylated glycoconjugates are transported to the cell membrane or packaged for secretion. On the other side, sialic acids on glycoconjugates can be released by sialidases (also termed as neuraminidases). There are four mammalian sialidases, NEU1-4. Lysosomal sialidase NEU1 initiates the degradation of sialoglycoconjugates [16-18]; cytosolic sialidase NEU2 exhibits highest activity with gangliosides [19,20]; the plasma membrane-associated sialidase NEU3 is specific for gangliosides [21]; and sialidase NEU4, which is bound to the outer mitochondrial membranes via protein-protein interactions or occurs in the lysosomal lumen, has a wide substrate specificity from glycoproteins to gangliosides and oligosaccharides [22]. The released sialic acids are pumped back into the cytosol, where they can enter another cycle of sialyl glycoconjugate production or be broken down by $\mathrm{N}$-acetylneuraminate lyase (NAL) to ManNAc and pyruvate [23]. Interestingly, Neu5Ac or ManNAc enter cells mainly through the pinocytic/endocytic pathways due to the lack of a specific transporter on the cell membrane [24].

In the following, we summarize the functions of sialic acids during tumor progression, especially in immune escape, tumor proliferation and metastasis, tumor angiogenesis and apoptosis resistance. Moreover, we also introduce the prevalent analytical methods, including the sialic acid quantification and labeling strategies by bio-affinity, the chemical reaction, and metabolic labeling.

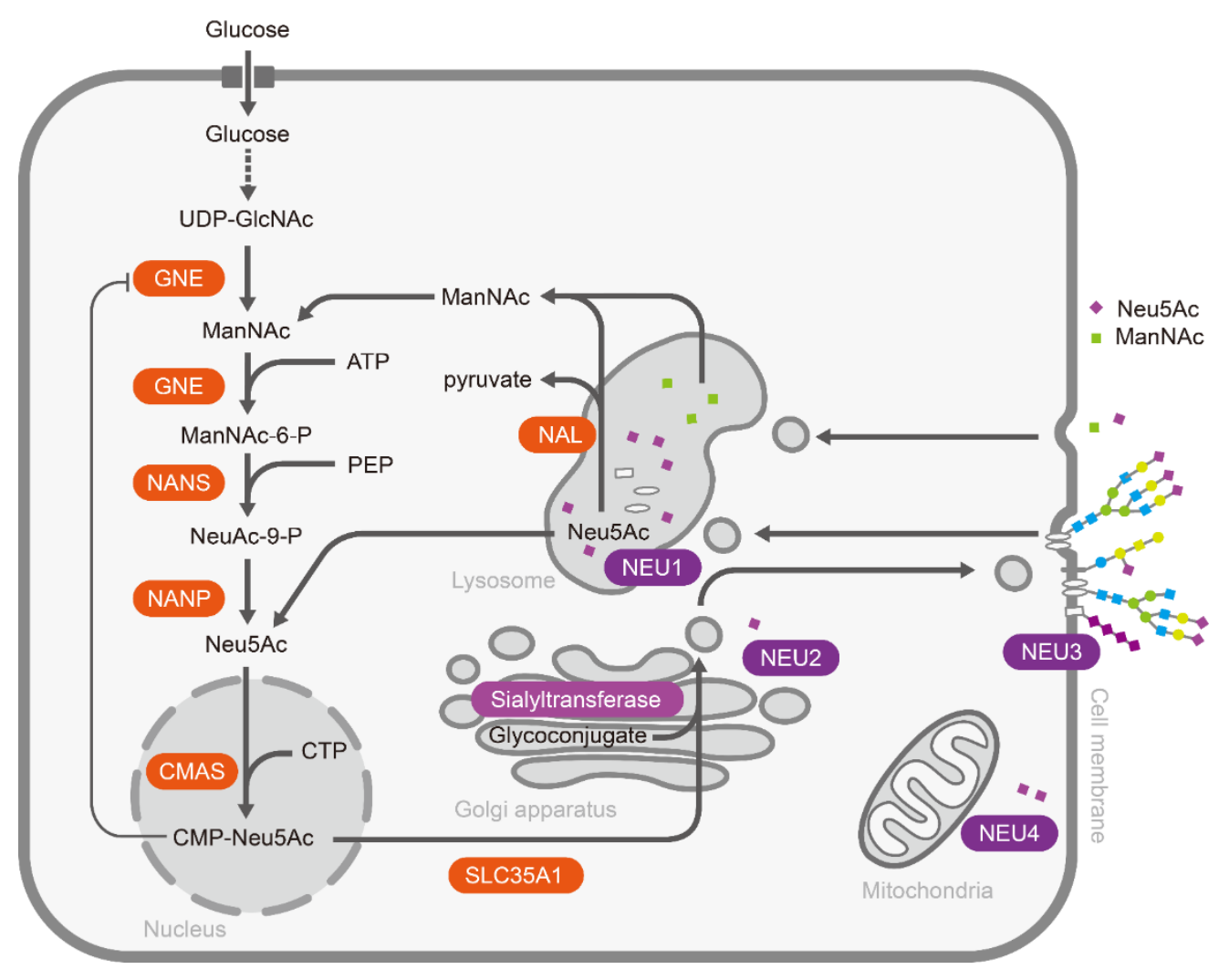

Figure 1. The metabolic pathway of sialic acids in mammalian cells. 


\section{Functions of Sialic Acids in Tumor Biology}

Sialic acids on tumor cell surfaces are aberrantly expressed during tumor transformation and malignant progression. In general, hypersialylation is frequently observed in tumor tissues compared to corresponding normal tissue [25]. The total sialic acid in serum or glycolipid-bound sialic acids is significantly elevated in multiple cancers such as ovarian cancer, leukemia, colorectal cancer, and breast cancer [26]. Polysialic acid is found at high expression levels on several types of cancer including glioma [27-29], neuroblastoma [30], and lung cancer [31]. Hypersialylation helps to accelerate cancer progression and leads to poor prognosis. The increased sialic acids in tumor cells are mainly caused by the special metabolic flux and aberrant expression of sialyltransferases/sialidases. Generally, tumor cells increase the uptake of glucose, the raw material for sialic acid synthesis. It was reported that sialic acid metabolism was upregulated in highly metastatic breast tumors, while knocking out CMAS gene, a key node in sialic acid metabolism, inhibited the synthesis of the activated form of sialic acid and decreased the formation of lung metastases in vivo [32]. On the other hand, the aberrant expression of sialyltransferases and sialidases accelerated and sustained sialylation status on glycoconjugates. The sialylation further facilitates immune escape, enhances tumor proliferation and metastasis, helps tumor angiogenesis, and assists in resisting apoptosis and cancer therapy (Figure 2).

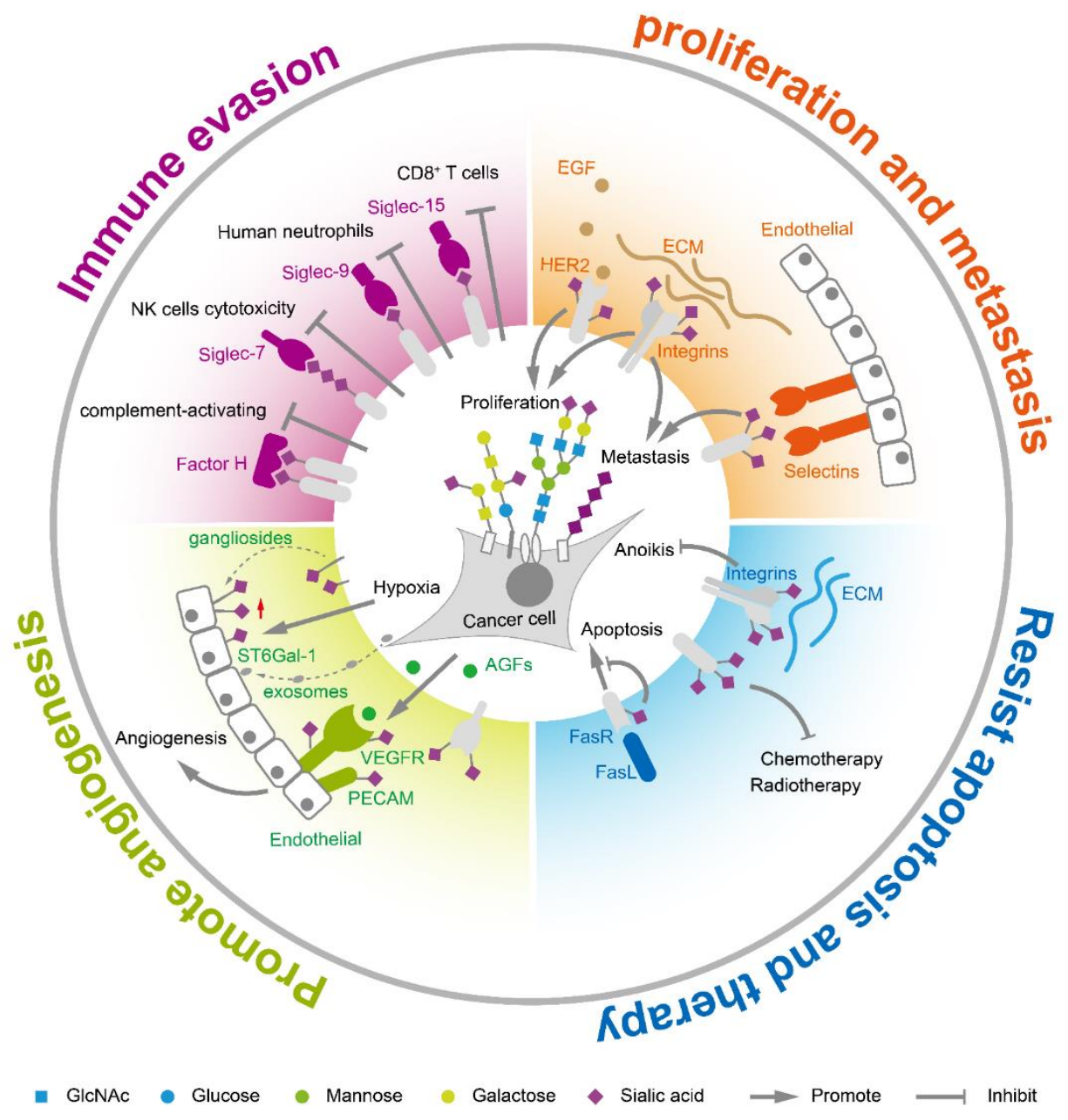

Figure 2. The functions of sialic acids in tumor biology.

\subsection{Sialic Acids Facilitate Immune Escape}

Growing evidence suggests that sialic acids control the immune homeostasis and weaken immune activation in order to avoid or limit the damage of sialylated cells [33]. Sialic acids act as 
self-associated patterns to maintain the baseline of innate immune cells [34]. Sialic acid recognizing receptors are the main molecules to transmit the inhibitory signals to the immune system. Highly coated sialyl glycans on tumor cells interacted with these sialic acid receptors to escape immune surveillance. There are three groups of sialic acid receptors: selectins, factor $\mathrm{H}$, and the family of sialic acid-binding immunoglobulin-like lectins (siglecs). The selectin family, including E-selectin, L-selectin and P-selectin, is related to tumor-associated inflammation [35]. Factor H is a central regulatory protein in the alternative complement pathway and binds $\alpha 2,3$-linked sialyl glycans in its C-terminal domain [36]. The complement pathway is a branch of the innate immune response that consists of numerous proteins that rapidly respond to microbial intruders, initiating the release of inflammatory mediators, phagocytic responses, and cell lysis. Sialyl glycans were suggested to prevent the activation of the complement system by recruitment of the complement control protein factor $\mathrm{H}$ to cell surface [37-39]. Siglecs are type I transmembrane proteins containing a sialic acid-binding site at $\mathrm{N}$-terminus, and most of them own one or more immunoreceptor tyrosine based inhibitory motifs at C-terminus. The binding of sialic acid ligands to immune inhibitory siglecs results in immune evasion [40-42]. For example, blocking siglec-2 (CD22), an inhibitory B cell receptor specifically recognizing $\alpha 2,6$ sialic acids, increased tumor sensitivity towards immunotherapy [43-45]. Similarly, inhibiting siglec-7 and siglec-9 could protect tumor cells from NK cell responses [46]. Sialyl ligands for siglec-9 on tumor cells inhibited neutrophil activation [47]. CD24 on tumor cells interacts with siglec-10 on tumor-associated macrophages to promote immune evasion [48]. Blocking siglec-15 or siglec- 9 disinhibited $\mathrm{T}$ cell activities and reduced tumor growth [49-51]. Focusing the immune inhibitory function of sialic acids and targeting sialic acid receptors offer potential important immunotherapy in cancer [52].

\subsection{Sialic Acids Enhance Tumor Proliferation and Metastasis}

Expression of sialylglycans are positively correlated with aggressiveness and metastasis in many cancers. Altered expression of sialylglycans is associated with epithelial-mesenchymal transition (EMT), an essential step for tumor progression and metastasis [53]. Transforming growth factor- $\beta$ (TGF- $\beta$ ) induced EMT process caused upregulation of various sialyltransferases such as ST3GAL1, ST3GAL2, ST6GAL1, ST6GAL2, ST8SIA1, ST8SIA2, and ST8SIA4 [54-61]. The upregulation of those sialyltransferases resulted in accumulation of sialylglycans on the cell surface, assisting tumor cells in surviving and metastasis. $\alpha 2,6$-sialylation in hepatocellular carcinoma activated $\mathrm{Wnt} / \beta$-catenin signaling to promote tumor cell proliferation, migration, and invasion [62]. Increased $\alpha 2,6$-sialylation on the human epidermal growth factor receptor 2 (HER2) facilitated gastric cancer progression via the Akt and ERK pathways [63]. Sialylation on the endothelial growth factors receptor (EGFR) was regulated by ST6GAL1 via the PI3K/Akt pathway [64], and inhibition of ST6GAL1 induced EGFR desialylation and anti-proliferation [65]. The $\alpha 2,6$-sialylated integrin $\alpha 5 \beta 1$ modulated FAK signaling and cell adhesion [66]. Polysialic acid controls tumor cell growth and differentiation by interfering with NCAM signaling at cell-cell contacts, as well as facilitates tumor invasion and metastasis $[27,58,60,67,68]$. Inhibiting polysialyltransferases ST8SIA2 and ST8SIA4 decreased polysialylation of NCAM, resulting in delayed metastasis in a xenograft rhabdomyosarcoma tumor mouse model [69]. Moreover, the sialyl glycans coated on tumor surface also contributed to their colonization during metastasis. For example, the enhanced sialylation, acting as ligands of selectin, which are vascular adhesion molecules, was associated with cancer progression and helped the adhesion and extravasation during metastasis [70-74].

\subsection{Sialic Acids Promote Tumor Angiogenesis}

Angiogenesis is the formation of new blood vessels from pre-existing ones, which is accurately controlled during embryonic development and wound repair. Around the microenvironment where tumor cells grow rapidly, new blood vessels are needed to meet the oxygen and nutrient requirements. Angiogenesis is stimulated by the angiogenic growth factors (AGFs), which are released by inflammatory 
cells or tumor cells. Among them, the most important AGF is the vascular endothelial growth factor (VEGF) family that includes VEGF-A, B, C, D, E, and placental growth factor [75]. VEGF affects angiogenesis by the interaction with polysialic acid [76]. Tumor cells grow in a hypoxia environment where sialic acids play an important role in tumor angiogenesis. Sialylation status could affect the growth factor-receptor interactions and related signal transduction in angiogenesis [77]. Gangliosides, one type of sialyl-glycosphingolipid, can be incorporated into the membrane of endothelial cells, increasing cell responsiveness to AGFs [78,79]. On the other hand, tumor cells can also regulate the sialic acid expression of surrounding cells by delivering ST6GAL1 through exosomes [80]. $\mathrm{N}$-glycans with terminal $\alpha 2,6$-sialylation on the receptors of blood vessels such as VEGFR2 are required for the VEGF engagement and proangiogenic activation of endothelial cells [81,82]. $\alpha 2,6$-sialylation mediates the homophilic interaction of the platelet endothelial cell adhesion molecule (PECAM). Sialylated PECAM interacted with two other sialylated receptors, VEGFR2 and integrin $\beta 3$, while the inhibition of sialylation in ST6GAL1 ${ }^{-1-}$ mice prevented PECAM-VEGFR2 interaction on the endothelial surface, inducing endothelial cell apoptosis and inhibiting angiogenesis [83].

\subsection{Sialic Acids Assist to Resist Apoptosis and Cancer Therapy}

Sialic acids affect cell apoptosis mainly through two pathways, the Fas receptor-Fas ligand (FasR-FasL) apoptotic pathway and anoikis. FasR-FasL interaction, induced through activated T cells and mediated by caspase activation, is important for homeostasis of cells in the immune system and for immune-privileged site maintenance in the human body [84]. Sialylated FasR blocked the binding of Fas-associated adaptor molecules to the FasR death domain, thus inhibiting the formation of the death-inducing signaling complex [85]. Sialyltransferase ST6GAL1 was found to elevate $\alpha 2,6$-sialylation on FasR to inhibit the apoptotic signaling in colon carcinoma cells [85]. Moreover, $\alpha 2,6$-sialylation impaired internalization of the Fas receptor and prevented further positive feedback loops for Fas-mediated apoptosis [86]. Anoikis is another cell death pathway induced by cell detachment from extracellular matrix (ECM). It is a vital mechanism in preventing adherent-independent cell growth and attachment to an inappropriate matrix [87]. Cancer cells showed a higher degree of anoikis resistance than the normal intestinal epithelial cells [88,89]. Integrin-mediated cell-ECM interactions are functionally involved in regulating tumor angiogenic response during cancer metastasis. The loss of integrin-mediated epithelial cell-ECM interactions decreases the phosphorylation of down streaming effectors such as FAK, PI3-K, ERK1, and MAP kinases, thus mediating cell susceptibility to anoikis [90]. However, $\alpha 2,6$-hypersialylation of fibronectin receptor integrin $\alpha 5 \beta 1$ could avoid anoikis by preventing galectin- 1 binding to integrins [91,92]. On the other hand, $\alpha 2,6$-sialylation showed vital effects on therapeutic resistance in many cancers [93-95], possibly through the sialylated receptors such as EGFR [96-98]. EGFR sialylation was reported to suppress its dimerization and to induce phosphorylation, reducing the effects of tyrosine kinase inhibitors [98].

\section{Sialic Acid Analysis Technology}

Since sialic acids have important functions in pathology and physiology, accurate, simple and rapid methods for sialic acid quantification and analysis have been developed, as summarized in Figure 3. 


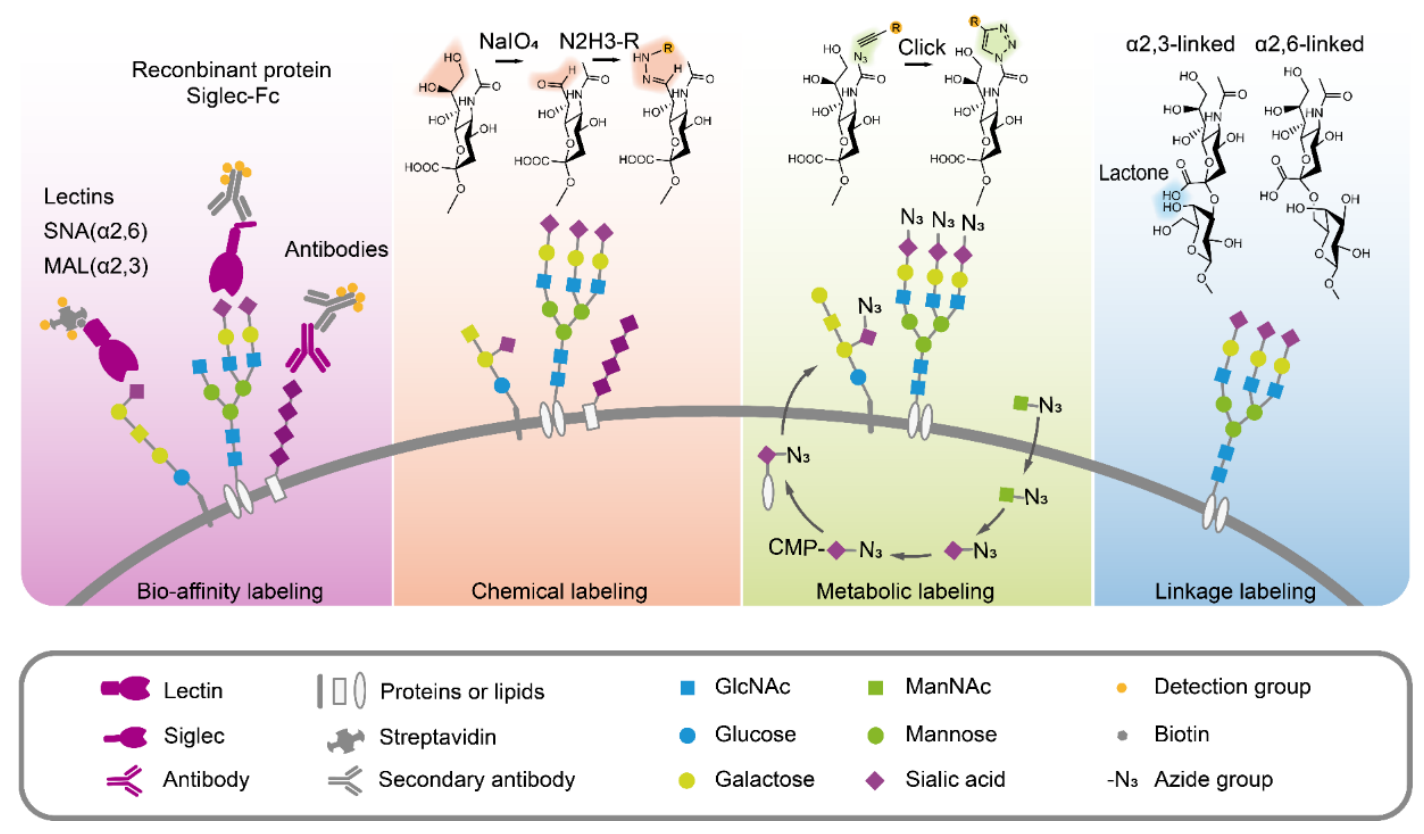

Figure 3. Different strategies for sialic acid analysis.

\subsection{Sialic Acids Quantification}

The high sensitivity of sialic acids in serum or plasma as a tumor marker has been reported in various cancerous conditions [26]. Quantification of total sialic acids or glycolipid-bound sialic acids in serum is helpful to improve the accuracy of clinical diagnoses and therapies. Detection methods have been established for quantification of sialic acids, including colorimetric assay [99], fluorometric assay [100,101], high performance liquid chromatography (HPLC) [102,103], fluorescence [104-106], and mass spectrometry (MS) [107-109]. Among those methods, HPLC and MS are widely used [110,111]. Free sialic acids are easy to detect using the above methods but the polysialic acid and the sialic acids bound on glycoconjugates need to be released by acid hydrolysis or neuraminidase. For HPLC analysis, the free sialic acids react with reagents to form chromogen, which can be measured based on their spectral absorption. Sample preparation involves non-derivatization or derivatization. Derivatizations could stabilize sialic acid and significantly enhance the detection sensitivity. The fluorogenic reagent, 1,2-diamino-4,5-methylenedioxybenzene (DMB) is commonly used to derivatize sialic acids. The DMB derivatives of sialic acids can be quantitatively analyzed by an HPLC system equipped with a fluorescence detector or by liquid chromatography electrospray ionization-mass spectrometry. Chromatographic separation, in particular, allows the successful separation of the sialic acids from interfering compounds using separation columns such as ion-exchange. For LC-MS analysis, MS is usually used as the detector, following LC separation, and the sialic acid structures can be easily distinguished by the precursor and fragmentation mass on MS. In summary, sialic acid in a complex sample could easily be quantified by the HPLC and MS method, which could be applied in tumor research and diagnosis [26]. For example, sialic acid, quantified with fluorescence detection-HPLC in the IgM-enriched fraction, was significantly higher in cancer patients [112]. The sialylated proteins, as potentially cancer-associated proteins in serum, were quantified in prostate cancer using LC-MS/MS [113,114].

\subsection{Sialic Acids Detection Through Bio-Affinity}

Over the past decade, several bio-affinity-based approaches for directly detecting sialic acids and sialylglycans have been developed, including lectins, antibodies, and recombinant sialic acid-binding proteins [115]. Lectins are sugar-binding proteins that can specifically recognize glycans on glycoconjugates. Sambucus nigra lectin (SNA) and Maackia amurensis lectin (MAL) are commonly used to 
recognize the $\alpha 2,6$-linked and $\alpha 2,3$-linked sialic acid residues, respectively [116-118], in lectin blot [119], lectin microarray [120-122], histochemistry [123], fluorescent image and flow cytometry [56,124]. Using lectin MAL-1, $\alpha 2,3$-linked sialic acids were found to promote gastric cancer cell metastasis [125]. Detecting sialic acids using antibodies is a routine strategy. However, antibodies against sialic acid are normally generated from carbohydrate antigens, and are usually immunoglobulin M (IgM) with low binding affinity. Antibodies only exhibited better affinity for polysialic acid with long-chain polymer [110]. Thus, antibodies are not widely used for detecting sialic acids [115]. Alternatively, the sialic acid receptors fused with tags or fluorescent protein have also been used in sialic acid detection. For example, Siglecs fused with the Fc portion of human IgG1 (Siglecs-Fc) were applied to the detection of sialylglycans [126]. Those methods provided a simple way to directly detect and visualize sialic acids in cells or tissues and to better understand the relationship between sialic acids and tumor progression.

\subsection{Chemical Modification to Label Sialic Acids}

Since the side chain at $\mathrm{C} 7, \mathrm{C} 8, \mathrm{C} 9$ of sialic acid is specifically sensitive to periodate oxidation under mild conditions, periodate oxidation has been designed to generate aldehyde groups from the sialic acids. This reaction selectively oxidizes the glycerol side chain of sialic acid to form a 7-aldehyde sialic acid derivative, which further can be linked to hydrazine beads or fluorescence probes and used for detecting the sialic acids on living cell surface $[116,127]$ and for glycoproteomic research. In this method, periodate oxidation imine ligation was improved by the presence of aniline for better efficiency [128]. Moreover, the aldehyde group also offers a possible way to quantify the sialoglycoconjugates. A rapid periodate oxidation of the sialic acid side chain in common core structures of gangliosides was carried out using $\mathrm{NaIO}_{4}$ treatment followed by ligation with a carbonyl-reactive isobaric tandem mass tag (TMT) and subsequent LC-MS/MS analysis. The TMT tag improved the ionization efficiency of complex gangliosides and could simultaneously quantify up to six samples, as well as the identification of glycan and lipid compositions in a single injection [129]. For $N$-glycans, triplex mdSUGAR tags were developed for quantitative glycomics. mdSUGAR tags could be easily linked to the reducing end of glycans and the additional aldehyde group introduced by mild periodate oxidation, which extend the mass difference and lower the requirement for resolving power [130]. In brief, a mild periodate oxidation reaction offers an efficient way to specifically and selectively oxidize the polyhydroxy chain of sialic acids to form the aldehyde group, which can be further linked to tags and fluorescence probes for enrichment or detection. Despite the potential side effects, the advantages of direct chemical labeling are still attractive. Samples from different sources such as cells, tissues, or biological fluids can be directly labeled after harvest at biocompatible reaction conditions with high ligation efficiency.

\subsection{Sialic Acids Metabolic Glycan Labeling}

As shown in Figure 1, the biosynthesis of sialic acids and sialyl glycoconjugates starts from UDP-N-acetylglucosamine (UDP-GlcNAc) enzymatic conversion. The exogenous sialic acid precursors, including ManNAc, sialic acid, and CMP-sialic acid, can be taken up and metabolized by mammalian cells, resulting in the high expression of sialic acids in cell surface sialoglycoconjugates. Due to the broader substrate tolerance of enzymes involved in sialylglycans biosynthesis, it is possible to use the sugar analogues with functional groups (e.g., ketones, azides, alkynes) for sialic acid metabolic labeling [131,132]. Theoretically, $N$-azido-acetylmannosamine (ManNAz) can be used in living cell surface glycans labeling. However, the absence of an efficient transporter and hydrophilic property limit ManNAz entering cells. Instead, the hydrophobic per-O-acetylated ManNAz (Ac ${ }_{4} \mathrm{ManNAz}$ ) was used for sialic acid metabolic labeling [133]. Ac ${ }_{4} \mathrm{ManNAz}$ can easily cross the cell membrane. After $\mathrm{Ac}_{4} \mathrm{ManNAz}$ have entered the cell, the extra acetyl groups are deacetylated by cytosolic esterases, and glycan biosynthetic enzymes can utilize these deprotected sugar derivatives [134]. Therefore, $\mathrm{Ac}_{4}$ ManNAz has been widely used in the cell surface sialic acid labeling, such as the sialoglycoprotein expression upon megakaryocytic differentiation [135], imaging the glycosylation state of cell surface 
glycoproteins [136], single cell [137] or selective cell [138] metabolic glycan labeling, imaging sialyl glycomics during zebrafish development [139]. Amazingly, using an $\mathrm{Ac}_{4} \mathrm{ManNAz}$ metabolic labeling strategy, sialylated $\mathrm{N}$-glycans on a select group of small noncoding RNAs (glycoRNAs), including Y RNAs, have been observed in mammalian cells [140], which may update our knowledge towards biochemistry, as we already know [141]. It is worth noting that per-O-acetylated monosaccharides can spontaneously react with numerous cysteines in proteomes with non-enzymatic catalysis, resulting in abnormal S-glycosylation [142]. In consideration of this condition, it is necessary to verify the results by specific glycosylation sites to exclude the S- glycosylation on cysteines when performing sialoglycoprotein research using $\mathrm{Ac}_{4}$ ManNAz. Despite the defect, metabolic labeling has been widely applied to cell engineering, chemical tumor targeting, and tumor therapy [143-145]. In summary, these metabolic glycan labeling methods can be efficiently used for the tracking and visualization of sialic acids, glycoproteome profiling and identifications, and the studies of sialic acid-dependent ligand-receptor interactions.

\subsection{Distinguishing the Sialic Acid Linkages}

Sialic acids are frequently the terminal residues of glycan chains and are typically connected either by a $\alpha 2,3-$ or $\alpha 2,6$-glycosidic bond to galactose (Gal) and/or $N$-acetylgalactosamine (GalNAc). Usually, lectins are used to recognize sialic acids with specific linkages. However, non-specific binding of lectin SNA and MAL makes the results unreliable. Considering the different spatial conformations, $\alpha 2,3$-linked sialic acid can form a stable lactone to the neighbor galactose, whereas $\alpha 2,6$-linked sialic acid cannot. This character makes it possible to differentiate the specific linkage of sialic acid on glycans through molecular weight. When sialylglycans were derivatized by dimethylamine, $\alpha 2,3$-linked sialic acid formed a stable amidation structure, which showed a mass shift of $-0.984 \mathrm{Da}$, whereas $\alpha 2,6$-linked sialic acid formed a stable dimethyl amide and remained stable in ammonium hydroxide, and the dimethylamidation of $\alpha 2,6$-linked sialic changed glycans mass by $+27.047 \mathrm{Da}$. The different mass shifts of $\alpha 2,3-$ and $\alpha 2,6$-linked sialic acid derivatives can be distinguished by MALDI-TOF MS [146]. Using this strategy, the profiling of sialic acids on IgG glycopeptides $[147,148]$, changes of sialic acid linkages in hypoxia condition of lung cancer A549 cells and in clinical ovarian cancer tissue [149,150], and the visualization of sialic acid on leiomyosarcoma tissues [151] have been successfully performed. In summary, this method offers an accurate way to explore the potential relationship between tumors and specific sialic acid linkages.

\section{Conclusions and Future Prospects}

In this review, we summarized the possible functions of sialic acids in tumor development and progression. Sialic acids commonly locate at the terminal of glycans on the cell surface. The negative charge and hydrophilic property give the sialic acid coated cells unique characters. Hypersialylation is usually found in tumor tissues and is supposed to be a potential hallmark of cancer. Sialic acids enhance tumor progression at multiple levels by facilitating escape from immunological surveillance, angiogenesis, the formation of metastasis, and resistance to apoptosis and therapy. For this reason, the therapeutic approaches to modulate sialic acids and their receptors can be of high potency in tumor therapy [152-154]. As the coated sialic acids on tumor cells masked the antigenic sites of glycoproteins, removing sialic acids by sialidases is expected to become potential treatment. Recently, co-expression of the surface sialidase in chimeric antigen receptor T-cells (CAR-T cells) has proven to be effective against solid tumors [155]. The sialylation on IgG was reported to induce anti-inflammation activity and to enhance stability and effector functions in antibody therapy $[153,154,156]$. Innovatively, engineering the glycan modification of extracellular vesicles by removing sialic acids and inserting Lewis ${ }^{Y}$ glycans enhanced the antigen presentation to dendritic cells, which might act as a "vaccine" for tumor treatment [157]. The polysialic acid modified liposomes were used as a targeted drug delivery system to enhance anti-cancer efficiency [158]. Moreover, antibody against siglec-15, a sialic acid 
binding protein and $\mathrm{T}$ cell depressor, is expected to apply to cancer immunotherapy, offering another therapeutic tool for cancer patients resistant to current anti-PD-1/PD-L1 therapy [49].

Fortunately, owing to novel technologies and methods, increasing discoveries of sialic acid functions in physiology and pathology are being reported. In clinical studies, sialylation in human serum or saliva can be accurately detected using quantification methods. Notably, specific proteins, such as IgA1 with sialylation, were proved to relate to certain tumor occurrences [159]. Enhanced levels of sialic acids in clinical serum provided a promising biomarker and a reliable predictor for prostate cancer and its bone metastases [160]. In fundamental research, more labeling methods are innovated, such as the chemical labeling after mild periodate oxidation and the sialic acid precursors analogues metabolic labeling. In recent years, chemists have designed various sugar analogues containing functional groups, making it more easy and convenient to label and track sialic acids [132]. Among those sugar analogues, $\mathrm{Ac}_{4} \mathrm{ManNAz}$ is mostly used as the azido group can be easily linked to probes or beads through click chemistry reaction. Sialic acid metabolic labeling combined with high resolution LC-MS offers simple detection in sialic acid modification sites of a certain protein [161]. As a result, analyzing the sialic acid modification in specific proteins enables researchers to explain the relationship between sialic acid modification and tumor progression in depth. We believe, in the near future, treatment such as reducing sialic acids or targeting the inhibitory sialic acid receptors, together with the immunotherapy, will release and rescue more patients suffering from cancer.

Author Contributions: Review writing and editing, X.Z.; supervision and revision, G.Y. and F.G. All authors have read and agreed to the published version of the manuscript.

Funding: This research was funded by the National Natural Science Foundation of China, grant number Nos. 31971211, 81672537; National Science and Technology Major Project of China, grant number 2018ZX10302205; Natural Science Foundation of Shaanxi Province, China, grant number 2019JZ-22 and Youth Innovation Team of Shaanxi Universities.

Acknowledgments: The authors are grateful to Dosher James Logan for performing English editing of the manuscript.

Conflicts of Interest: The authors declare no conflict of interest.

\section{Abbreviations}

$\begin{array}{ll}\text { Ac}_{4} \text { ManNAz } & \text { Per-O-acetylated N-azido-acetylmannosamine; } \\ \text { AGF } & \text { Angiogenic growth factor; } \\ \text { CMAS } & \text { Cytosine } 5^{\prime} \text {-monophosphate } N \text {-acetylneuraminic acid synthetase; } \\ \text { CAR-T cell } & \text { Chimeric antigen receptor T-Cell; } \\ \text { CMAH } & \text { Cytidine monophosphate } N \text {-acetylneuraminic acid hydroxylase; } \\ \text { CMP-Neu5Ac } & \text { Cytidine-5'-monophospho- } N \text {-acetylneuraminic acid; } \\ \text { EGF } & \text { Epidermal growth factor; } \\ \text { EGFR } & \text { Epidermal growth factor receptor; } \\ \text { EMT } & \text { Epithelial-mesenchymal transition; } \\ \text { ERK } & \text { Extracellular signal-regulated kinases; } \\ \text { FAK } & \text { Focal adhesion kinase; } \\ \text { FC } & \text { The fragment crystallizable region of antibody; } \\ \text { GalNAc } & N \text {-acetylgalactosamine; } \\ \text { GNE } & \text { Hydrolyzing UDP-GlcNAc 2-epimerase/ManNAc-6-kinase; } \\ \text { HER } & \text { Human epidermal growth factor receptor; } \\ \text { HPLC } & \text { High performance liquid chromatography; } \\ \text { IgA/G/M } & \text { Immunoglobulin A/G/M; } \\ \text { ITIM } & \text { Immunoreceptor tyrosine based inhibitory motif; } \\ \text { LC-MS } & \text { Liquid chromatography-mass spectrometry; } \\ \text { LSA } & \text { Glycolipid-bound sialic acids; } \\ \text { MAL } & \text { Maackia amurensis lectin; } \\ \text { MALDI-TOF MS } & \text { Matrix-assisted laser desorption/ionization time of flight mass spectrometry; } \\ \text { ManNAc } & N \text {-acetyl-D-mannosamine; } \\ & \end{array}$




$\begin{array}{ll}\text { MAP } & \text { Mitogen-activated protein; } \\ \text { MS } & \text { Mass spectrometry; } \\ \text { NAL } & \text { N-acetylneuraminate lyase; } \\ \text { NANP } & \text { Neu5Ac-9-phosphate phosphatase; } \\ \text { NANS } & \text { Neu5Ac 9-phosphate synthase; } \\ \text { NCAM } & \text { Neural cell adhesion molecule; } \\ \text { NEU } & \text { Neuraminidase; sialidase; acetylneuraminyl hydrolase; } \\ \text { Neu5Ac } & \text { N-acetylneuraminic acid; } \\ \text { Neu5Gc } & \text { N-glycolylneuraminic acid; } \\ \text { NK cell } & \text { Natural killer cell; } \\ \text { PD-1/PD-L1 } & \text { Programmed cell death protein 1/ligand 1; } \\ \text { PECAM } & \text { Platelet endothelial cells adhesion molecule; } \\ \text { PEP } & \text { Phosphoenolpyruvate; } \\ \text { Siglec } & \text { Sialic acid-binding immunoglobulin-like lectins; } \\ \text { SNA } & \text { Sambucus nigra lectin; } \\ \text { TMT } & \text { Tandem mass tag; } \\ \text { TSA } & \text { Total sialic acid; } \\ \text { UDP-GlcNAc } & \text { Uridine diphosphate N-acetylglucosamine; } \\ \text { VEGF } & \text { Vascular endothelial growth factor; } \\ \text { VEGFR } & \text { Vascular endothelial growth factor receptor. }\end{array}$

\section{References}

1. Blix, G.; Svennerholm, L.; Werner, I.; Finsnes, E.; Sörensen, J.S.; Sörensen, N.A. The Isolation of Chondrosamine from Gangliosides and from Submaxillary Mucin. Acta Chem. Scand. 1952, 6, 358-362. [CrossRef]

2. Schauer, R.; Kamerling, J.P. Exploration of the Sialic Acid World. Adv. Carbohydr. Chem. Biochem. 2018, 75, 1-213. [PubMed]

3. Chou, H.H.; Takematsu, H.; Diaz, S.; Iber, J.; Nickerson, E.; Wright, K.L.; Muchmore, E.A.; Nelson, D.L.; Warren, S.T.; Varki, A. A mutation in human CMP-sialic acid hydroxylase occurred after the Homo-Pan divergence. Proc. Natl. Acad. Sci. USA 1998, 95, 11751-11756. [CrossRef] [PubMed]

4. Chou, H.H.; Hayakawa, T.; Diaz, S.; Krings, M.; Indriati, E.; Leakey, M.; Paabo, S.; Satta, Y.; Takahata, N.; Varki, A. Inactivation of CMP-N-acetylneuraminic acid hydroxylase occurred prior to brain expansion during human evolution. Proc. Natl. Acad. Sci. USA 2002, 99, 11736-11741. [CrossRef]

5. Altman, M.O.; Gagneux, P. Absence of Neu5Gc and Presence of Anti-Neu5Gc Antibodies in Humans-An Evolutionary Perspective. Front. Immunol. 2019, 10, 789. [CrossRef]

6. Tangvoranuntakul, P.; Gagneux, P.; Diaz, S.; Bardor, M.; Varki, N.; Varki, A.; Muchmore, E. Human uptake and incorporation of an immunogenic nonhuman dietary sialic acid. Proc. Natl. Acad. Sci. USA 2003, 100, 12045-12050. [CrossRef]

7. Varki, A.; Cummings, R.D.; Esko, J.D.; Stanley, P.; Hart, G.W.; Aebi, M.; Darvill, A.G.; Kinoshita, T.; Packer, N.H.; Prestegard, J.H.; et al. Essentials of Glycobiology, 3rd ed.; Cold Spring Harbor Laboratory Press: Cold Spring Harbor, NY, USA, 2017.

8. Muhlenhoff, M.; Rollenhagen, M.; Werneburg, S.; Gerardy-Schahn, R.; Hildebrandt, H. Polysialic acid: Versatile modification of NCAM, SynCAM 1 and neuropilin-2. Neurochem. Res. 2013, 38, 1134-1143. [CrossRef]

9. Schnaar, R.L.; Gerardy-Schahn, R.; Hildebrandt, H. Sialic acids in the brain: Gangliosides and polysialic acid in nervous system development, stability, disease, and regeneration. Physiol. Rev. 2014, 94, 461-518. [CrossRef]

10. Tanner, M.E. The enzymes of sialic acid biosynthesis. Bioorg. Chem. 2005, 33, 216-228. [CrossRef]

11. Stasche, R.; Hinderlich, S.; Weise, C.; Effertz, K.; Lucka, L.; Moormann, P.; Reutter, W. A bifunctional enzyme catalyzes the first two steps in $\mathrm{N}$-acetylneuraminic acid biosynthesis of rat liver. Molecular cloning and functional expression of UDP- $N$-acetyl-glucosamine 2-epimerase/ $\mathrm{N}$-acetylmannosamine kinase. J. Biol. Chem. 1997, 272, 24319-24324. [CrossRef] 
12. Lucka, L.; Krause, M.; Danker, K.; Reutter, W.; Horstkorte, R. Primary structure and expression analysis of human UDP-N-acetyl-glucosamine-2-epimerase/ $N$-acetylmannosamine kinase, the bifunctional enzyme in neuraminic acid biosynthesis1. FEBS Lett. 1999, 454, 341-344.

13. Maliekal, P.; Vertommen, D.; Delpierre, G.; Van Schaftingen, E. Identification of the sequence encoding $N$-acetylneuraminate-9-phosphate phosphatase. Glycobiology 2006, 16, 165-172. [CrossRef]

14. Li, Y.; Chen, X. Sialic acid metabolism and sialyltransferases: Natural functions and applications. Appl. Microbiol. Biotechnol. 2012, 94, 887-905. [CrossRef]

15. Munster-Kuhnel, A.K.; Tiralongo, J.; Krapp, S.; Weinhold, B.; Ritz-Sedlacek, V.; Jacob, U.; Gerardy-Schahn, R. Structure and function of vertebrate CMP-sialic acid synthetases. Glycobiology 2004, 14, 43R-51R. [CrossRef]

16. Bonten, E.; van der Spoel, A.; Fornerod, M.; Grosveld, G.; d'Azzo, A. Characterization of human lysosomal neuraminidase defines the molecular basis of the metabolic storage disorder sialidosis. Genes Dev. 1996, 10, 3156-3169. [CrossRef]

17. Maurice, P.; Baud, S.; Bocharova, O.V.; Bocharov, E.V.; Kuznetsov, A.S.; Kawecki, C.; Bocquet, O.; Romier, B.; Gorisse, L.; Ghirardi, M.; et al. New Insights into Molecular Organization of Human Neuraminidase-1: Transmembrane Topology and Dimerization Ability. Sci. Rep. 2016, 6, 38363. [CrossRef]

18. Bao, L.; Ding, L.; Hui, J.; Ju, H. A light-up imaging protocol for neutral pH-enhanced fluorescence detection of lysosomal neuraminidase activity in living cells. Chem. Commun. 2016, 52, 12897-12900. [CrossRef]

19. Chavas, L.M.; Tringali, C.; Fusi, P.; Venerando, B.; Tettamanti, G.; Kato, R.; Monti, E.; Wakatsuki, S. Crystal structure of the human cytosolic sialidase Neu2. Evidence for the dynamic nature of substrate recognition. J. Biol. Chem. 2005, 280, 469-475. [CrossRef]

20. Monti, E.; Preti, A.; Rossi, E.; Ballabio, A.; Borsani, G. Cloning and characterization of NEU2, a human gene homologous to rodent soluble sialidases. Genomics 1999, 57, 137-143. [CrossRef]

21. Miyagi, T.; Wada, T.; Iwamatsu, A.; Hata, K.; Yoshikawa, Y.; Tokuyama, S.; Sawada, M. Molecular cloning and characterization of a plasma membrane-associated sialidase specific for gangliosides. J. Biol. Chem. 1999, 274, 5004-5011. [CrossRef]

22. Monti, E.; Bassi, M.T.; Bresciani, R.; Civini, S.; Croci, G.L.; Papini, N.; Riboni, M.; Zanchetti, G.; Ballabio, A.; Preti, A.; et al. Molecular cloning and characterization of NEU4, the fourth member of the human sialidase gene family. Genomics 2004, 83, 445-453. [CrossRef] [PubMed]

23. Schauer, R.; Sommer, U.; Kruger, D.; van Unen, H.; Traving, C. The terminal enzymes of sialic acid metabolism: Acylneuraminate pyruvate-lyases. Biosci. Rep. 1999, 19, 373-383. [CrossRef] [PubMed]

24. Bardor, M.; Nguyen, D.H.; Diaz, S.; Varki, A. Mechanism of uptake and incorporation of the non-human sialic acid N-glycolylneuraminic acid into human cells. J. Biol. Chem. 2005, 280, 4228-4237. [CrossRef] [PubMed]

25. Bull, C.; Stoel, M.A.; den Brok, M.H.; Adema, G.J. Sialic acids sweeten a tumor's life. Cancer Res. 2014, 74, 3199-3204. [CrossRef] [PubMed]

26. Zhang, Z.; Wuhrer, M.; Holst, S. Serum sialylation changes in cancer. Glycoconj. J. 2018, 35, $139-160$. [CrossRef]

27. Suzuki, M.; Suzuki, M.; Nakayama, J.; Suzuki, A.; Angata, K.; Chen, S.; Sakai, K.; Hagihara, K.; Yamaguchi, Y.; Fukuda, M. Polysialic acid facilitates tumor invasion by glioma cells. Glycobiology 2005, 15, 887-894. [CrossRef]

28. Petridis, A.K.; Wedderkopp, H.; Hugo, H.H.; Maximilian Mehdorn, H. Polysialic acid overexpression in malignant astrocytomas. Acta Neurochir. 2009, 151, 601-604. [CrossRef]

29. Amoureux, M.C.; Coulibaly, B.; Chinot, O.; Loundou, A.; Metellus, P.; Rougon, G.; Figarella-Branger, D. Polysialic acid neural cell adhesion molecule (PSA-NCAM) is an adverse prognosis factor in glioblastoma, and regulates olig2 expression in glioma cell lines. BMC Cancer 2010, 10, 91. [CrossRef]

30. Glüer, S.; Schelp, C.; Gerardy-Schahn, R.; von Schweinitz, D. Polysialylated neural cell adhesion molecule as a marker for differential diagnosis in pediatric tumors. J. Pediatr. Surg. 1998, 33, 1516-1520. [CrossRef]

31. Lantuejoul, S.; Moro, D.; Michalides, R.J.; Brambilla, C.; Brambilla, E. Neural cell adhesion molecules (NCAM) and NCAM-PSA expression in neuroendocrine lung tumors. Am. J. Surg. Pathol. 1998, 22, 1267-1276. [CrossRef]

32. Teoh, S.T.; Ogrodzinski, M.P.; Ross, C.; Hunter, K.W.; Lunt, S.Y. Sialic Acid Metabolism: A Key Player in Breast Cancer Metastasis Revealed by Metabolomics. Front. Oncol. 2018, 8, 174. [CrossRef] [PubMed]

33. Bull, C.; den Brok, M.H.; Adema, G.J. Sweet escape: Sialic acids in tumor immune evasion. Biochim. Biophys. Acta 2014, 1846, 238-246. [CrossRef] [PubMed] 
34. Varki, A. Since there are PAMPs and DAMPs, there must be SAMPs? Glycan "self-associated molecular patterns" dampen innate immunity, but pathogens can mimic them. Glycobiology 2011, 21, 1121-1124. [CrossRef] [PubMed]

35. Barthel, S.R.; Gavino, J.D.; Descheny, L.; Dimitroff, C.J. Targeting selectins and selectin ligands in inflammation and cancer. Expert Opin. Ther. Targets 2007, 11, 1473-1491. [CrossRef] [PubMed]

36. Blaum, B.S.; Hannan, J.P.; Herbert, A.P.; Kavanagh, D.; Uhrin, D.; Stehle, T. Structural basis for sialic acid-mediated self-recognition by complement factor H. Nat. Chem. Biol. 2015, 11, 77-82. [CrossRef]

37. Afshar-Kharghan, V. The role of the complement system in cancer. J. Clin. Investig. 2017, 127, 780-789. [CrossRef]

38. Reis, E.S.; Mastellos, D.C.; Ricklin, D.; Mantovani, A.; Lambris, J.D. Complement in cancer: Untangling an intricate relationship. Nat. Rev. Immunol. 2018, 18, 5-18. [CrossRef]

39. Abeln, M.; Albers, I.; Peters-Bernard, U.; Flachsig-Schulz, K.; Kats, E.; Kispert, A.; Tomlinson, S.; Gerardy-Schahn, R.; Munster-Kuhnel, A.; Weinhold, B. Sialic acid is a critical fetal defense against maternal complement attack. J. Clin. Investig. 2019, 129, 422-436. [CrossRef]

40. Macauley, M.S.; Crocker, P.R.; Paulson, J.C. Siglec-mediated regulation of immune cell function in disease. Nat. Rev. Immunol. 2014, 14, 653-666. [CrossRef]

41. Stanczak, M.A.; Siddiqui, S.S.; Trefny, M.P.; Thommen, D.S.; Boligan, K.F.; von Gunten, S.; Tzankov, A.; Tietze, L.; Lardinois, D.; Heinzelmann-Schwarz, V.; et al. Self-associated molecular patterns mediate cancer immune evasion by engaging Siglecs on T cells. J. Clin. Investig. 2018, 128, 4912-4923. [CrossRef]

42. Daly, J.; Carlsten, M.; O’Dwyer, M. Sugar Free: Novel Immunotherapeutic Approaches Targeting Siglecs and Sialic Acids to Enhance Natural Killer Cell Cytotoxicity Against Cancer. Front. Immunol. 2019, $10,1047$. [CrossRef] [PubMed]

43. Guedan, S.; Delgado, J. Immobilizing a Moving Target: CAR T Cells Hit CD22. Clin. Cancer Res. 2019, 25, 5188-5190. [CrossRef] [PubMed]

44. Tsubata, T. Inhibitory B cell co-receptors and autoimmune diseases. Immunol. Med. 2019, 42, $108-116$. [CrossRef] [PubMed]

45. Bednar, K.J.; Shanina, E.; Ballet, R.; Connors, E.P.; Duan, S.; Juan, J.; Arlian, B.M.; Kulis, M.D.; Butcher, E.C.; Fung-Leung, W.P.; et al. Human CD22 Inhibits Murine B Cell Receptor Activation in a Human CD22 Transgenic Mouse Model. J. Immunol. 2017, 199, 3116-3128. [CrossRef] [PubMed]

46. Jandus, C.; Boligan, K.F.; Chijioke, O.; Liu, H.; Dahlhaus, M.; Demoulins, T.; Schneider, C.; Wehrli, M.; Hunger, R.E.; Baerlocher, G.M.; et al. Interactions between Siglec-7/9 receptors and ligands influence NK cell-dependent tumor immunosurveillance. J. Clin. Investig. 2014, 124, 1810-1820. [CrossRef] [PubMed]

47. Laubli, H.; Pearce, O.M.; Schwarz, F.; Siddiqui, S.S.; Deng, L.; Stanczak, M.A.; Deng, L.; Verhagen, A.; Secrest, P.; Lusk, C.; et al. Engagement of myelomonocytic Siglecs by tumor-associated ligands modulates the innate immune response to cancer. Proc. Natl. Acad. Sci. USA 2014, 111, 14211-14216. [CrossRef] [PubMed]

48. Barkal, A.A.; Brewer, R.E.; Markovic, M.; Kowarsky, M.; Barkal, S.A.; Zaro, B.W.; Krishnan, V.; Hatakeyama, J.; Dorigo, O.; Barkal, L.J.; et al. CD24 signalling through macrophage Siglec-10 is a target for cancer immunotherapy. Nature 2019, 572, 392-396. [CrossRef]

49. Wang, J.; Sun, J.; Liu, L.N.; Flies, D.B.; Nie, X.; Toki, M.; Zhang, J.; Song, C.; Zarr, M.; Zhou, X.; et al. Siglec-15 as an immune suppressor and potential target for normalization cancer immunotherapy. Nat. Med. 2019, 25, 656-666. [CrossRef]

50. Cornelissen, L.A.M.; Blanas, A.; van der Horst, J.C.; Kruijssen, L.; Zaal, A.; O'Toole, T.; Wiercx, L.; van Kooyk, Y.; van Vliet, S.J. Disruption of sialic acid metabolism drives tumor growth by augmenting CD8(+) T cell apoptosis. Int. J. Cancer 2019, 144, 2290-2302. [CrossRef]

51. Bull, C.; Boltje, T.J.; Balneger, N.; Weischer, S.M.; Wassink, M.; van Gemst, J.J.; Bloemendal, V.R.; Boon, L.; van der Vlag, J.; Heise, T.; et al. Sialic Acid Blockade Suppresses Tumor Growth by Enhancing T-cell-Mediated Tumor Immunity. Cancer Res. 2018, 78, 3574-3588. [CrossRef]

52. Cao, G.; Xiao, Z.; Yin, Z. Normalization cancer immunotherapy: Blocking Siglec-15! Signal Transduct. Target. Ther. 2019, 4, 10. [CrossRef] [PubMed]

53. Du, J.; Hong, S.; Dong, L.; Cheng, B.; Lin, L.; Zhao, B.; Chen, Y.G.; Chen, X. Dynamic Sialylation in Transforming Growth Factor-beta (TGF-beta)-induced Epithelial to Mesenchymal Transition. J. Biol. Chem. 2015, 290, 12000-12013. [CrossRef] [PubMed] 
54. Wu, X.; Zhao, J.; Ruan, Y.; Sun, L.; Xu, C.; Jiang, H. Sialyltransferase ST3GAL1 promotes cell migration, invasion, and TGF-beta1-induced EMT and confers paclitaxel resistance in ovarian cancer. Cell Death Dis. 2018, 9, 1102. [CrossRef]

55. Yeo, H.L.; Fan, T.C.; Lin, R.J.; Yu, J.C.; Liao, G.S.; Chen, E.S.; Ho, M.Y.; Lin, W.D.; Chen, K.; Chen, C.H.; et al. Sialylation of vasorin by ST3Gal1 facilitates TGF-beta1-mediated tumor angiogenesis and progression. Int. J. Cancer 2019, 144, 1996-2007. [CrossRef] [PubMed]

56. Lu, J.; Isaji, T.; Im, S.; Fukuda, T.; Hashii, N.; Takakura, D.; Kawasaki, N.; Gu, J. beta-Galactoside alpha2,6-sialyltranferase 1 promotes transforming growth factor-beta-mediated epithelial-mesenchymal transition. J. Biol. Chem. 2014, 289, 34627-34641. [CrossRef] [PubMed]

57. Choi, H.J.; Chung, T.W.; Choi, H.J.; Han, J.H.; Choi, J.H.; Kim, C.H.; Ha, K.T. Increased alpha2-6 sialylation of endometrial cells contributes to the development of endometriosis. Exp. Mol. Med. 2018, 50, 164. [CrossRef]

58. Wang, X.; Li, X.; Zeng, Y.N.; He, F.; Yang, X.M.; Guan, F. Enhanced expression of polysialic acid correlates with malignant phenotype in breast cancer cell lines and clinical tissue samples. Int. J. Mol. Med. 2016, 37, 197-206. [CrossRef]

59. Guo, D.; Guo, J.; Li, X.; Guan, F. Differential effects of Pax3 on expression of polysialyltransferases STX and PST in TGF-beta-treated normal murine mammary gland cells. Exp. Biol. Med. 2017, 242, 177-183. [CrossRef]

60. Falconer, R.A.; Errington, R.J.; Shnyder, S.D.; Smith, P.J.; Patterson, L.H. Polysialyltransferase: A new target in metastatic cancer. Curr. Cancer Drug Targets 2012, 12, 925-939. [CrossRef]

61. Hao, J.; Zeltz, C.; Pintilie, M.; Li, Q.; Sakashita, S.; Wang, T.; Cabanero, M.; Martins-Filho, S.N.; Wang, D.Y.; Pasko, E.; et al. Characterization of Distinct Populations of Carcinoma-Associated Fibroblasts from Non-Small Cell Lung Carcinoma Reveals a Role for ST8SIA2 in Cancer Cell Invasion. Neoplasia 2019, 21, 482-493. [CrossRef]

62. Zhao, Y.; Wei, A.; Zhang, H.; Chen, X.; Wang, L.; Zhang, H.; Yu, X.; Yuan, Q.; Zhang, J.; Wang, S. alpha2,6-Sialylation mediates hepatocellular carcinoma growth in vitro and in vivo by targeting the Wnt/beta-catenin pathway. Oncogenesis 2017, 6, e343. [CrossRef] [PubMed]

63. Liu, N.; Zhu, M.; Linhai, Y.; Song, Y.; Gui, X.; Tan, G.; Li, J.; Liu, Y.; Deng, Z.; Chen, X.; et al. Increasing HER2 alpha2,6 sialylation facilitates gastric cancer progression and resistance via the Akt and ERK pathways. Oncol. Rep. 2018, 40, 2997-3005. [PubMed]

64. Liu, Q.; Ma, H.; Sun, X.; Liu, B.; Xiao, Y.; Pan, S.; Zhou, H.; Dong, W.; Jia, L. The regulatory ZFAS1/miR-150/ST6GAL1 crosstalk modulates sialylation of EGFR via PI3K/Akt pathway in T-cell acute lymphoblastic leukemia. J. Exp. Clin. Cancer Res. 2019, 38, 199. [CrossRef] [PubMed]

65. Chang, T.C.; Chin, Y.T.; Nana, A.W.; Wang, S.H.; Liao, Y.M.; Chen, Y.R.; Shih, Y.J.; Changou, C.A.; Yang, Y.S.; Wang, K.; et al. Enhancement by Nano-Diamino-Tetrac of Antiproliferative Action of Gefitinib on Colorectal Cancer Cells: Mediation by EGFR Sialylation and PI3K Activation. Horm. Cancer 2018, 9, 420-432. [CrossRef]

66. Yu, S.; Fan, J.; Liu, L.; Zhang, L.; Wang, S.; Zhang, J. Caveolin-1 up-regulates integrin alpha2,6-sialylation to promote integrin alpha5beta1-dependent hepatocarcinoma cell adhesion. FEBS Lett. 2013, 587, 782-787. [CrossRef]

67. Seidenfaden, R.; Krauter, A.; Schertzinger, F.; Gerardy-Schahn, R.; Hildebrandt, H. Polysialic acid directs tumor cell growth by controlling heterophilic neural cell adhesion molecule interactions. Mol. Cell. Biol. 2003, 23, 5908-5918. [CrossRef]

68. Lu, B.; Liu, X.H.; Liao, S.M.; Lu, Z.L.; Chen, D.; Troy Ii, F.A.; Huang, R.B.; Zhou, G.P. A Possible Modulation Mechanism of Intramolecular and Intermolecular Interactions for NCAM Polysialylation and Cell Migration. Curr. Top. Med. Chem. 2019, 19, 2271-2282. [CrossRef]

69. Somplatzki, S.; Muhlenhoff, M.; Kroger, A.; Gerardy-Schahn, R.; Boldicke, T. Intrabodies against the Polysialyltransferases ST8SiaII and ST8SiaIV inhibit Polysialylation of NCAM in rhabdomyosarcoma tumor cells. BMC Biotechnol. 2017, 17, 42. [CrossRef]

70. Hauselmann, I.; Roblek, M.; Protsyuk, D.; Huck, V.; Knopfova, L.; Grassle, S.; Bauer, A.T.; Schneider, S.W.; Borsig, L. Monocyte Induction of E-Selectin-Mediated Endothelial Activation Releases VE-Cadherin Junctions to Promote Tumor Cell Extravasation in the Metastasis Cascade. Cancer Res. 2016, 76, 5302-5312. [CrossRef]

71. Li, S.S.; Ip, C.K.M.; Tang, M.Y.H.; Tang, M.K.S.; Tong, Y.; Zhang, J.; Hassan, A.A.; Mak, A.S.C.; Yung, S.; Chan, T.M.; et al. Sialyl Lewis(x)-P-selectin cascade mediates tumor-mesothelial adhesion in ascitic fluid shear flow. Nat. Commun. 2019, 10, 2406. [CrossRef] 
72. Julien, S.; Ivetic, A.; Grigoriadis, A.; QiZe, D.; Burford, B.; Sproviero, D.; Picco, G.; Gillett, C.; Papp, S.L.; Schaffer, L.; et al. Selectin ligand sialyl-Lewis $\mathrm{x}$ antigen drives metastasis of hormone-dependent breast cancers. Cancer Res. 2011, 71, 7683-7693. [CrossRef]

73. Suzuki, Y.; Haraguchi, N.; Takahashi, H.; Uemura, M.; Nishimura, J.; Hata, T.; Takemasa, I.; Mizushima, T.; Ishii, H.; Doki, Y.; et al. SSEA-3 as a novel amplifying cancer cell surface marker in colorectal cancers. Int. J. Oncol. 2013, 42, 161-167.

74. Cheung, S.K.; Chuang, P.K.; Huang, H.W.; Hwang-Verslues, W.W.; Cho, C.H.; Yang, W.B.; Shen, C.N.; Hsiao, M.; Hsu, T.L.; Chang, C.F.; et al. Stage-specific embryonic antigen-3 (SSEA-3) and beta3GalT5 are cancer specific and significant markers for breast cancer stem cells. Proc. Natl. Acad. Sci. USA 2016, 113, 960-965. [CrossRef] [PubMed]

75. Simons, M.; Gordon, E.; Claesson-Welsh, L. Mechanisms and regulation of endothelial VEGF receptor signalling. Nat. Rev. Mol. Cell Biol. 2016, 17, 611-625. [CrossRef] [PubMed]

76. Strubl, S.; Schubert, U.; Kuhnle, A.; Rebl, A.; Ahmadvand, N.; Fischer, S.; Preissner, K.T.; Galuska, S.P. Polysialic acid is released by human umbilical vein endothelial cells (HUVEC) in vitro. Cell Biosci. 2018, 8, 64. [CrossRef] [PubMed]

77. Chiodelli, P.; Urbinati, C.; Paiardi, G.; Monti, E.; Rusnati, M. Sialic acid as a target for the development of novel antiangiogenic strategies. Future Med. Chem. 2018, 10, 2835-2854. [CrossRef] [PubMed]

78. Rusnati, M.; Urbinati, C.; Tanghetti, E.; Dell'Era, P.; Lortat-Jacob, H.; Presta, M. Cell membrane GM1 ganglioside is a functional coreceptor for fibroblast growth factor 2. Proc. Natl. Acad. Sci. USA 2002, 99, 4367-4372. [CrossRef] [PubMed]

79. Liu, Y.; McCarthy, J.; Ladisch, S. Membrane ganglioside enrichment lowers the threshold for vascular endothelial cell angiogenic signaling. Cancer Res. 2006, 66, 10408-10414. [CrossRef]

80. Zhang, Q.; Higginbotham, J.N.; Jeppesen, D.K.; Yang, Y.P.; Li, W.; McKinley, E.T.; Graves-Deal, R.; Ping, J.; Britain, C.M.; Dorsett, K.A.; et al. Transfer of Functional Cargo in Exomeres. Cell Rep. 2019, 27, $940-954$. [CrossRef]

81. Chandler, K.B.; Leon, D.R.; Meyer, R.D.; Rahimi, N.; Costello, C.E. Site-Specific N-Glycosylation of Endothelial Cell Receptor Tyrosine Kinase VEGFR-2. J. Proteome Res. 2017, 16, 677-688. [CrossRef]

82. Chiodelli, P.; Rezzola, S.; Urbinati, C.; Federici Signori, F.; Monti, E.; Ronca, R.; Presta, M.; Rusnati, M. Contribution of vascular endothelial growth factor receptor-2 sialylation to the process of angiogenesis. Oncogene 2017, 36, 6531-6541. [CrossRef]

83. Imamaki, R.; Ogawa, K.; Kizuka, Y.; Komi, Y.; Kojima, S.; Kotani, N.; Honke, K.; Honda, T.; Taniguchi, N.; Kitazume, S. Glycosylation controls cooperative PECAM-VEGFR2-beta3 integrin functions at the endothelial surface for tumor angiogenesis. Oncogene 2018, 37, 4287-4299. [CrossRef] [PubMed]

84. Waring, P.; Mullbacher, A. Cell death induced by the Fas/Fas ligand pathway and its role in pathology. Immunol. Cell Biol. 1999, 77, 312-317. [CrossRef] [PubMed]

85. Swindall, A.F.; Bellis, S.L. Sialylation of the Fas death receptor by ST6Gal-I provides protection against Fas-mediated apoptosis in colon carcinoma cells. J. Biol. Chem. 2011, 286, 22982-22990. [CrossRef]

86. Lee, K.H.; Feig, C.; Tchikov, V.; Schickel, R.; Hallas, C.; Schutze, S.; Peter, M.E.; Chan, A.C. The role of receptor internalization in CD95 signaling. EMBO J. 2006, 25, 1009-1023. [CrossRef]

87. Liotta, L.A.; Kohn, E. Anoikis: Cancer and the homeless cell. Nature 2004, 430, 973-974. [CrossRef]

88. Cao, Z.; Livas, T.; Kyprianou, N. Anoikis and EMT: Lethal “Liaisons” during Cancer Progression. Crit. Rev. Oncog. 2016, 21, 155-168. [CrossRef]

89. Guha, D.; Saha, T.; Bose, S.; Chakraborty, S.; Dhar, S.; Khan, P.; Adhikary, A.; Das, T.; Sa, G. Integrin-EGFR interaction regulates anoikis resistance in colon cancer cells. Apoptosis 2019, 24, 958-971. [CrossRef]

90. Lee, Y.C.; Jin, J.K.; Cheng, C.J.; Huang, C.F.; Song, J.H.; Huang, M.; Brown, W.S.; Zhang, S.; Yu-Lee, L.Y.; Yeh, E.T.; et al. Targeting constitutively activated beta1 integrins inhibits prostate cancer metastasis. Mol. Cancer Res. 2013, 11, 405-417. [CrossRef]

91. Zhuo, Y.; Bellis, S.L. Emerging role of alpha2,6-sialic acid as a negative regulator of galectin binding and function. J. Biol. Chem. 2011, 286, 5935-5941. [CrossRef]

92. Zhuo, Y.; Chammas, R.; Bellis, S.L. Sialylation of $\beta 1$ Integrins Blocks Cell Adhesion to Galectin-3 and Protects Cells against Galectin-3-induced Apoptosis. J. Biol. Chem. 2008, 283, 22177-22185. [CrossRef] [PubMed]

93. Park, J.J.; Lee, M. Increasing the alpha 2, 6 sialylation of glycoproteins may contribute to metastatic spread and therapeutic resistance in colorectal cancer. Gut Liver 2013, 7, 629-641. [CrossRef] [PubMed] 
94. Schultz, M.J.; Swindall, A.F.; Wright, J.W.; Sztul, E.S.; Landen, C.N.; Bellis, S.L. ST6Gal-I sialyltransferase confers cisplatin resistance in ovarian tumor cells. J. Ovarian Res. 2013, 6, 25. [CrossRef] [PubMed]

95. Chakraborty, A.; Dorsett, K.A.; Trummell, H.Q.; Yang, E.S.; Oliver, P.G.; Bonner, J.A.; Buchsbaum, D.J.; Bellis, S.L. ST6Gal-I sialyltransferase promotes chemoresistance in pancreatic ductal adenocarcinoma by abrogating gemcitabine-mediated DNA damage. J. Biol. Chem. 2018, 293, 984-994. [CrossRef] [PubMed]

96. Park, J.J.; Yi, J.Y.; Jin, Y.B.; Lee, Y.J.; Lee, J.S.; Lee, Y.S.; Ko, Y.G.; Lee, M. Sialylation of epidermal growth factor receptor regulates receptor activity and chemosensitivity to gefitinib in colon cancer cells. Biochem. Pharmacol. 2012, 83, 849-857. [CrossRef] [PubMed]

97. Britain, C.M.; Holdbrooks, A.T.; Anderson, J.C.; Willey, C.D.; Bellis, S.L. Sialylation of EGFR by the ST6Gal-I sialyltransferase promotes EGFR activation and resistance to gefitinib-mediated cell death. J. Ovarian Res. 2018, 11, 12. [CrossRef] [PubMed]

98. Yen, H.Y.; Liu, Y.C.; Chen, N.Y.; Tsai, C.F.; Wang, Y.T.; Chen, Y.J.; Hsu, T.L.; Yang, P.C.; Wong, C.H. Effect of sialylation on EGFR phosphorylation and resistance to tyrosine kinase inhibition. Proc. Natl. Acad. Sci. USA 2015, 112, 6955-6960. [CrossRef]

99. Skoza, L.; Mohos, S. Stable thiobarbituric acid chromophore with dimethyl sulphoxide. Application to sialic acid assay in analytical de-O-acetylation. Biochem. J. 1976, 159, 457-462. [CrossRef]

100. Hammond, K.S.; Papermaster, D.S. Fluorometric assay of sialic acid in the picomole range: A modification of the thiobarbituric acid assay. Anal. Biochem. 1976, 74, 292-297. [CrossRef]

101. Shukla, A.K.; Schauer, R. Fluorimetric determination of unsubstituted and 9(8)-O-acetylated sialic acids in erythrocyte membranes. Hoppe Seylers Z. Physiol. Chem. 1982, 363, 255-262. [CrossRef]

102. Rohrer, J.S.; Thayer, J.; Weitzhandler, M.; Avdalovic, N. Analysis of the N-acetylneuraminic acid and $\mathrm{N}$-glycolylneuraminic acid contents of glycoproteins by high-pH anion-exchange chromatography with pulsed amperometric detection. Glycobiology 1998, 8, 35-43. [CrossRef] [PubMed]

103. Hurum, D.C.; Rohrer, J.S. Five-minute glycoprotein sialic acid determination by high-performance anion exchange chromatography with pulsed amperometric detection. Anal. Biochem. 2011, 419, 67-69. [CrossRef] [PubMed]

104. Hara, S.; Yamaguchi, M.; Takemori, Y.; Nakamura, M.; Ohkura, Y. Highly sensitive determination of $\mathrm{N}$-acetyl- and $\mathrm{N}$-glycolylneuraminic acids in human serum and urine and rat serum by reversed-phase liquid chromatography with fluorescence detection. J. Chromatogr. B Biomed. Sci. Appl. 1986, 377, 111-119. [CrossRef]

105. Hara, S.; Takemori, Y.; Yamaguchi, M.; Nakamura, M.; Ohkura, Y. Fluorometric high-performance liquid chromatography of $\mathrm{N}$-acetyl- and $\mathrm{N}$-glycolylneuraminic acids and its application to their microdetermination in human and animal sera, glycoproteins, and glycolipids. Anal. Biochem. 1987, 164, 138-145. [CrossRef]

106. Kawabata, A.; Morimoto, N.; Oda, Y.; Kinoshita, M.; Kuroda, R.; Kakehi, K. Determination of mucin in salivary glands using sialic acids as the marker by high-performance liquid chromatography with fluorometric detection. Anal. Biochem. 2000, 283, 119-121. [CrossRef]

107. Klein, A.; Diaz, S.; Ferreira, I.; Lamblin, G.; Roussel, P.; Manzi, A.E. New sialic acids from biological sources identified by a comprehensive and sensitive approach: Liquid chromatography-electrospray ionization-mass spectrometry (LC-ESI-MS) of SIA quinoxalinones. Glycobiology 1997, 7, 421-432. [CrossRef] [PubMed]

108. Tebani, A.; Schlemmer, D.; Imbard, A.; Rigal, O.; Porquet, D.; Benoist, J.F. Measurement of free and total sialic acid by isotopic dilution liquid chromatography tandem mass spectrometry method. J. Chromatogr. B Analyt. Technol. Biomed. Life Sci. 2011, 879, 3694-3699. [CrossRef] [PubMed]

109. van den Bosch, J.; Oemardien, L.F.; Srebniak, M.I.; Piraud, M.; Huijmans, J.G.; Verheijen, F.W.; Ruijter, G.J. Prenatal screening of sialic acid storage disease and confirmation in cultured fibroblasts by LC-MS/MS. J. Inherit. Metab. Dis. 2011, 34, 1069-1073. [CrossRef]

110. Guo, X.; Elkashef, S.M.; Loadman, P.M.; Patterson, L.H.; Falconer, R.A. Recent advances in the analysis of polysialic acid from complex biological systems. Carbohydr. Polym. 2019, 224, 115145. [CrossRef]

111. Nishikaze, T. Sialic acid derivatization for glycan analysis by mass spectrometry. Proc. Jpn. Acad. Ser. B Phys. Biol. Sci. 2019, 95, 523-537. [CrossRef]

112. Torii, T.; Kanemitsu, K.; Hagiwara, A. Sialic acid level is significantly elevated in IgM enriched protein fraction in sera of cancer patients. J. Immunoass. Immunochem. 2017, 38, 127-139. [CrossRef] [PubMed] 
113. Gabriele, C.; Cantiello, F.; Nicastri, A.; Crocerossa, F.; Russo, G.I.; Cicione, A.; Vartolomei, M.D.; Ferro, M.; Morgia, G.; Lucarelli, G.; et al. High-throughput detection of low abundance sialylated glycoproteins in human serum by $\mathrm{TiO}_{2}$ enrichment and targeted LC-MS/MS analysis: Application to a prostate cancer sample set. Anal. Bioanal. Chem. 2019, 411, 755-763. [CrossRef] [PubMed]

114. Zhang, Q.; Li, Z.; Wang, Y.; Zheng, Q.; Li, J. Mass spectrometry for protein sialoglycosylation. Mass Spectrom. Rev. 2018, 37, 652-680. [CrossRef] [PubMed]

115. Zhang, X.; Nie, H.; Whited, J.; Wang, D.; Li, Y.; Sun, X.L. Recent approaches for directly profiling cell surface sialoform. Glycobiology 2018, 28, 910-924. [CrossRef]

116. Zeng, Y.; Ramya, T.N.; Dirksen, A.; Dawson, P.E.; Paulson, J.C. High-efficiency labeling of sialylated glycoproteins on living cells. Nat. Methods 2009, 6, 207-209. [CrossRef]

117. Geisler, C.; Jarvis, D.L. Effective glycoanalysis with Maackia amurensis lectins requires a clear understanding of their binding specificities. Glycobiology 2011, 21, 988-993. [CrossRef]

118. Broekaert, W.F.; Nsimba-Lubaki, M.; Peeters, B.; Peumans, W.J. A lectin from elder (Sambucus nigra L.) bark. Biochem. J. 1984, 221, 163-169. [CrossRef]

119. Wu, G.; Nagala, M.; Crocker, P.R. Identification of lectin counter-receptors on cell membranes by proximity labeling. Glycobiology 2017, 27, 800-805. [CrossRef]

120. Robajac, D.; Masnikosa, R.; Nemcovic, M.; Krizakova, M.; Belicka Klukova, L.; Barath, P.; Katrlik, J.; Nedic, O. Glycoanalysis of the placental membrane glycoproteins throughout placental development. Mech. Ageing Dev. 2019, 183, 111151. [CrossRef]

121. Du, H.; Yu, H.; Ma, T.; Yang, F.; Jia, L.; Zhang, C.; Zhang, J.; Niu, L.; Yang, J.; Zhang, Z.; et al. Analysis of Glycosphingolipid Glycans by Lectin Microarrays. Anal. Chem. 2019, 91, 10663-10671. [CrossRef]

122. Tateno, H.; Uchiyama, N.; Kuno, A.; Togayachi, A.; Sato, T.; Narimatsu, H.; Hirabayashi, J. A novel strategy for mammalian cell surface glycome profiling using lectin microarray. Glycobiology 2007, 17, 1138-1146. [CrossRef] [PubMed]

123. Fukasawa, T.; Asao, T.; Yamauchi, H.; Ide, M.; Tabe, Y.; Fujii, T.; Yamaguchi, S.; Tsutsumi, S.; Yazawa, S.; Kuwano, H. Associated expression of alpha2,3sialylated type 2 chain structures with lymph node metastasis in distal colorectal cancer. Surg. Today 2013, 43, 155-162. [CrossRef] [PubMed]

124. Wang, D.; Nie, H.; Ozhegov, E.; Wang, L.; Zhou, A.; Li, Y.; Sun, X.L. Globally profiling sialylation status of macrophages upon statin treatment. Glycobiology 2015, 25, 1007-1015. [CrossRef]

125. Shen, L.; Luo, Z.; Wu, J.; Qiu, L.; Luo, M.; Ke, Q.; Dong, X. Enhanced expression of alpha2,3-linked sialic acids promotes gastric cancer cell metastasis and correlates with poor prognosis. Int. J. Oncol. 2017, 50, 1201-1210. [CrossRef]

126. Blixt, O.; Collins, B.E.; van den Nieuwenhof, I.M.; Crocker, P.R.; Paulson, J.C. Sialoside specificity of the siglec family assessed using novel multivalent probes: Identification of potent inhibitors of myelin-associated glycoprotein. J. Biol. Chem. 2003, 278, 31007-31019. [CrossRef] [PubMed]

127. De Bank, P.A.; Kellam, B.; Kendall, D.A.; Shakesheff, K.M. Surface engineering of living myoblasts via selective periodate oxidation. Biotechnol. Bioeng. 2003, 81, 800-808. [CrossRef] [PubMed]

128. Key, J.A.; Li, C.; Cairo, C.W. Detection of cellular sialic acid content using nitrobenzoxadiazole carbonyl-reactive chromophores. Bioconjug. Chem. 2012, 23, 363-371. [CrossRef] [PubMed]

129. Barrientos, R.C.; Zhang, Q. Isobaric Labeling of Intact Gangliosides toward Multiplexed LC-MS/MS-Based Quantitative Analysis. Anal. Chem. 2018, 90, 2578-2586. [CrossRef]

130. Feng, Y.; Li, M.; Lin, Y.; Chen, B.; Li, L. Multiplex Quantitative Glycomics Enabled by Periodate Oxidation and Triplex Mass Defect Isobaric Multiplex Reagents for Carbonyl-Containing Compound Tags. Anal. Chem. 2019, 91, 11932-11937. [CrossRef]

131. Saxon, E.; Bertozzi, C.R. Cell surface engineering by a modified Staudinger reaction. Science 2000, 287, 2007-2010. [CrossRef]

132. Sminia, T.J.; Zuilhof, H.; Wennekes, T. Getting a grip on glycans: A current overview of the metabolic oligosaccharide engineering toolbox. Carbohydr. Res. 2016, 435, 121-141. [CrossRef] [PubMed]

133. Hsu, T.L.; Hanson, S.R.; Kishikawa, K.; Wang, S.K.; Sawa, M.; Wong, C.H. Alkynyl sugar analogs for the labeling and visualization of glycoconjugates in cells. Proc. Natl. Acad. Sci. USA 2007, 104, 2614-2619. [CrossRef] [PubMed]

134. Palaniappan, K.K.; Bertozzi, C.R. Chemical Glycoproteomics. Chem. Rev. 2016, 116, 14277-14306. [CrossRef] [PubMed] 
135. Yu, S.H.; Zhao, P.; Sun, T.; Gao, Z.; Moremen, K.W.; Boons, G.J.; Wells, L.; Steet, R. Selective Exo-Enzymatic Labeling Detects Increased Cell Surface Sialoglycoprotein Expression upon Megakaryocytic Differentiation. J. Biol. Chem. 2016, 291, 3982-3989. [CrossRef] [PubMed]

136. Belardi, B.; de la Zerda, A.; Spiciarich, D.R.; Maund, S.L.; Peehl, D.M.; Bertozzi, C.R. Imaging the glycosylation state of cell surface glycoproteins by two-photon fluorescence lifetime imaging microscopy. Angew. Chem. Int. Ed. Engl. 2013, 52, 14045-14049. [CrossRef] [PubMed]

137. Zhou, Z.-R.; Wang, X.-Y.; Lv, J.; Chen, B.-B.; Tang, Y.-B.; Qian, R.-C. Nanopipette-assisted single cell metabolic glycan labeling. RSC Adv. 2019, 9, 30666-30670. [CrossRef]

138. Xie, R.; Hong, S.; Feng, L.; Rong, J.; Chen, X. Cell-selective metabolic glycan labeling based on ligand-targeted liposomes. J. Am. Chem. Soc. 2012, 134, 9914-9917. [CrossRef]

139. Dehnert, K.W.; Baskin, J.M.; Laughlin, S.T.; Beahm, B.J.; Naidu, N.N.; Amacher, S.L.; Bertozzi, C.R. Imaging the sialome during zebrafish development with copper-free click chemistry. ChemBioChem 2012, 13, 353-357. [CrossRef]

140. Flynn, R.A.; Smith, B.A.H.; Johnson, A.G.; Pedram, K.; George, B.M.; Malaker, S.A.; Majzoub, K.; Carette, J.E.; Bertozzi, C.R. Mammalian Y RNAs are modified at discrete guanosine residues with N-glycans. bioRxiv 2019. [CrossRef]

141. Service, R. Sugar-coated RNAs could 'alter the face of biochemistry as we know it'-If they're real. Science 2019. [CrossRef]

142. Qin, W.; Qin, K.; Fan, X.; Peng, L.; Hong, W.; Zhu, Y.; Lv, P.; Du, Y.; Huang, R.; Han, M.; et al. Artificial Cysteine S-Glycosylation Induced by Per-O-Acetylated Unnatural Monosaccharides during Metabolic Glycan Labeling. Angew. Chem. Int. Ed. Engl. 2018, 57, 1817-1820. [CrossRef] [PubMed]

143. Lee, S.; Koo, H.; Na, J.H.; Han, S.J.; Min, H.S.; Lee, S.J.; Kim, S.H.; Yun, S.H.; Jeong, S.Y.; Kwon, I.C.; et al. Chemical tumor-targeting of nanoparticles based on metabolic glycoengineering and click chemistry. ACS Nano 2014, 8, 2048-2063. [CrossRef] [PubMed]

144. Kim, K.S.; Lee, J.Y.; Han, J.; Hwang, H.S.; Lee, J.; Na, K. Local Immune-Triggered Surface-Modified Stem Cells for Solid Tumor Immunotherapy. Adv. Funct. Mater. 2019, 29. [CrossRef]

145. Koo, H.; Lee, S.; Na, J.H.; Kim, S.H.; Hahn, S.K.; Choi, K.; Kwon, I.C.; Jeong, S.Y.; Kim, K. Bioorthogonal copper-free click chemistry in vivo for tumor-targeted delivery of nanoparticles. Angew. Chem. Int. Ed. Engl. 2012, 51, 11836-11840. [CrossRef]

146. Reiding, K.R.; Blank, D.; Kuijper, D.M.; Deelder, A.M.; Wuhrer, M. High-throughput profiling of protein $\mathrm{N}$-glycosylation by MALDI-TOF-MS employing linkage-specific sialic acid esterification. Anal. Chem. 2014, 86, 5784-5793. [CrossRef]

147. de Haan, N.; Reiding, K.R.; Haberger, M.; Reusch, D.; Falck, D.; Wuhrer, M. Linkage-specific sialic acid derivatization for MALDI-TOF-MS profiling of IgG glycopeptides. Anal. Chem. 2015, 87, 8284-8291. [CrossRef]

148. Bondt, A.; Rombouts, Y.; Selman, M.H.; Hensbergen, P.J.; Reiding, K.R.; Hazes, J.M.; Dolhain, R.J.; Wuhrer, M. Immunoglobulin $\mathrm{G}$ (IgG) Fab glycosylation analysis using a new mass spectrometric high-throughput profiling method reveals pregnancy-associated changes. Mol. Cell. Proteom. 2014, 13, 3029-3039. [CrossRef]

149. Dedova, T.; Braicu, E.I.; Sehouli, J.; Blanchard, V. Sialic Acid Linkage Analysis Refines the Diagnosis of Ovarian Cancer. Front. Oncol. 2019, 9, 261. [CrossRef]

150. Zhou, X.; Yang, S.; Yang, G.; Tan, Z.; Guan, F. Two-step derivatization and mass spectral distinction of $\alpha 2,3$ and $\alpha 2,6$ sialic acid linkages on N-glycans by MALDI-TOF. Chin. Chem. Lett. 2019, 30, 676-680. [CrossRef]

151. Holst, S.; Heijs, B.; de Haan, N.; van Zeijl, R.J.; Briaire-de Bruijn, I.H.; van Pelt, G.W.; Mehta, A.S.; Angel, P.M.; Mesker, W.E.; Tollenaar, R.A.; et al. Linkage-Specific in Situ Sialic Acid Derivatization for N-Glycan Mass Spectrometry Imaging of Formalin-Fixed Paraffin-Embedded Tissues. Anal. Chem. 2016, 88, 5904-5913. [CrossRef]

152. Munkley, J.; Scott, E. Targeting Aberrant Sialylation to Treat Cancer. Medicines 2019, 6, 102. [CrossRef] [PubMed]

153. Kaneko, Y.; Nimmerjahn, F.; Ravetch, J.V. Anti-inflammatory activity of immunoglobulin G resulting from Fc sialylation. Science 2006, 313, 670-673. [CrossRef] [PubMed]

154. Knorr, D.A.; Ravetch, J.V. Immunotherapy and Hyperprogression: Unwanted Outcomes, Unclear Mechanism. Clin. Cancer Res. 2019, 25, 904-906. [CrossRef] [PubMed] 
155. King, T.; Posey, A.D. Co-expression of an engineered cell-surface sialidase by CART cells improves anti-cancer activity of NK cells in solid tumors. Cytotherapy 2019, 21, S27. [CrossRef]

156. Chen, C.L.; Hsu, J.C.; Lin, C.W.; Wang, C.H.; Tsai, M.H.; Wu, C.Y.; Wong, C.H.; Ma, C. Crystal Structure of a Homogeneous IgG-Fc Glycoform with the N-Glycan Designed to Maximize the Antibody Dependent Cellular Cytotoxicity. ACS Chem. Biol. 2017, 12, 1335-1345. [CrossRef]

157. Dusoswa, S.A.; Horrevorts, S.K.; Ambrosini, M.; Kalay, H.; Paauw, N.J.; Nieuwland, R.; Pegtel, M.D.; Wurdinger, T.; Van Kooyk, Y.; Garcia-Vallejo, J.J. Glycan modification of glioblastoma-derived extracellular vesicles enhances receptor-mediated targeting of dendritic cells. J. Extracell. Vesicles 2019, 8, 1648995. [CrossRef]

158. Zhang, T.; Zhou, S.; Hu, L.; Peng, B.; Liu, Y.; Luo, X.; Liu, X.; Song, Y.; Deng, Y. Polysialic acid-polyethylene glycol conjugate-modified liposomes as a targeted drug delivery system for epirubicin to enhance anticancer efficiency. Drug Deliv. Transl. Res. 2018, 8, 602-616. [CrossRef]

159. Lomax-Browne, H.J.; Robertson, C.; Antonopoulos, A.; Leathem, A.J.C.; Haslam, S.M.; Dell, A.; Dwek, M.V. Serum IgA1 shows increased levels of alpha2,6-linked sialic acid in breast cancer. Interface Focus 2019, 9, 20180079. [CrossRef]

160. Zhang, C.; Yan, L.; Song, H.; Ma, Z.; Chen, D.; Yang, F.; Fang, L.; Li, Z.; Li, K.; Li, D.; et al. Elevated Serum Sialic Acid Levels Predict Prostate Cancer As Well As Bone Metastases. J. Cancer 2019, 10, 449-457. [CrossRef]

161. Yu, A.; Zhao, J.; Peng, W.; Banazadeh, A.; Williamson, S.D.; Goli, M.; Huang, Y.; Mechref, Y. Advances in mass spectrometry-based glycoproteomics. Electrophoresis 2018, 39, 3104-3122. [CrossRef]

(C) 2020 by the authors. Licensee MDPI, Basel, Switzerland. This article is an open access article distributed under the terms and conditions of the Creative Commons Attribution (CC BY) license (http://creativecommons.org/licenses/by/4.0/). 